\title{
Deforestation and Disaster Mitigation: Policy Analysis for the Prevention and Enforcement of Forest Function Change in Bima
}

\author{
Aman Ma'arij* \\ Law Studies Program \\ Muhammadiyah Bima School of Law \\ Bima, Indonesia \\ amanmarijstih@gmail.com \\ R Ridwan \\ Law Studies Program \\ Muhammadiyah Bima School of Law \\ Bima, Indonesia
}

\author{
M. Firdaus \\ Law Studies Program \\ Muhammadiyah Bima School of Law \\ Bima, Indonesia \\ S Sukirman \\ Law Studies Program \\ Muhammadiyah Bima School of Law \\ Bima, Indonesia
}

\begin{abstract}
This article is the result of research on environmental degradation. Forests have a very important and vital function in human life, i.e., socially, economically, and other aspects. Therefore, forests need to be preserved and utilized to ensure it sustainability. Forest destruction due to illegal logging and other causes is a complex problem to solve and has long implications that also impact the future generation. This is a general condition of forest in Indonesia, specifically in the City and District of Bima, where the impact of forest destruction can be felt during the rainy and dry season. In the rainy season, there is flash flood, heat, and air pollution, meanwhile in the dry season it has an impact on fire, drought, and lack of clean water. The results of the study found that the pattern of forest destruction in the district and city of Bima was caused by illegal logging, forest encroachment, and land conversion. It mostly triggered by economic demands, low public awareness, and lack of socialization from the authorities. From this research, it is hoped that efforts will be born to reduce disaster risk, either through policies for prevention, action, diversion and / or physical development as well as awareness and increased ability to face disaster threats in the community of City and District of Bima. The result of the study will also be beneficial to emerge some efforts to prevent the forest destruction which is carried out in the form of conducting patrols, afforestation or reforestation, and installing strut or girdle wires.
\end{abstract}

Keywords—deforestation, mitigation, disasters, policy, forests

\section{INTRODUCTION}

Indonesia's forests with an area of 133.6 million hectares are the lungs of the earth, the future continuity of life on earth is closely related to the carrying capacity of the environment, especially forests. Forests, which are a gift and a mandate from God Almighty as a gift, are priceless natural resources that must be grateful and maintained for their continuity and utilization of both ecological, socio-cultural and economic benefits, in a balanced and dynamic manner for both present and future generations [1]. In order to obtain optimal benefits from forests and forest areas for the welfare of the community, in principle all forests and forest areas can be utilized while still taking into account their nature, characteristics and vulnerability, and not changing the main function of the forest. Utilization of forests and forest areas must be adjusted to their main functions, namely the functions of conservation, protection and production. To maintain the sustainability of the main functions of the forest and the condition of the forest, efforts are also made to rehabilitate and reclaim forest and land, with the aim of not only restoring forest quality but also increasing community empowerment and welfare. To maintain environmental quality, the use of forests should avoids the occurrence of conversion from natural forests that are still productive to become plantation forests (Law No.41/ 1999) [2].

In its empirical reality, it contrasts with the function and essence of the existence of forests as the capital and gift of God, in fact the rate of forest destruction is almost uncontrolled as a result of the conversion of functions by illegal means. Indonesia ranks second in the world as a country with the rate of forest destruction. There are 684,000 hectares of Indonesian forests damaged each year [3]. In the City and District of Bima, the rate of forest destruction as a result of conversion of forest functions and illegal logging is quite concerning, more than $50 \%$ of the forest has changed its function and is badly damaged. almost every year there are natural disasters one after another. For instance, the rainy season is followed by flood, summer fires, and shortage of clean water [4]

Research on forest destruction and conversion of forest functions that cause natural disasters is important based on the following considerations. First, natural disasters in the City and District of Bima, both in the form of flash floods, drought, lack of clean water, fires, crop failure every year always occurs and recurs. Second, the rate of destruction and transition of forest functions is increasingly out of control. Third, to explain the extent of preventive efforts by the two District Governments and the City of Bima in overcoming the rate of damage and conversion of forest functions. Fourth, reveal the extent of the role of law enforcement against the perpetrators of forest destruction and diversion. Fifth, reveal whether the policies taken so far have been able to minimize or prevent recurring natural disasters. The output of this research is expected to be able to develop an ideal concept in terms of effective prevention of damage and conversion of forest functions which are the main factors of natural disasters that routinely hit cities and districts. Bima-NTB. This concept 
then becomes the basis for formulating policies, especially the participatory collaborative concept involving all stakeholders and the participation of local communities through the local wisdom approach.

\section{METHODS}

This research is an empirical legal research. Referring to Mukti Fajar, this type of empirical legal research is a legal research method that uses empirical facts taken from human behavior, both verbal behavior obtained from interviews and real behavior through direct observation. Empirical legal research is also used to observe the results of human behavior in the form of physical remains and archives [5]. Here, law is interpreted as the result of social symptoms, or the result of patterned patterns of social interaction. The research approach is carried out with approaches, cases, conceptual approaches and policy approaches. Research locations, conducted in the City of Bima and the District of Bima, West Nusa Tenggara (NTB) - Indonesia. Data collection was carried out by in-depth interviews with informants, people who experience environmental impacts and are subject to environmental damage. The main source of data is primary data, which is obtained from, 1). In-depth and structured interviews with informants and resource persons; 2). The results of the observations, regarding the environmental damage that often occurs in Bima, are supported by secondary data obtained from (a) primary law, such as statutory regulations, judge decisions, doctrine, and others; (b) secondary legal materials in the form of references to books, journals, etc.; and (c) tertiary legal materials in the form of dictionaries and encyclopedias. Besides in-depth interviews, observations were also carried as a method to collect the data. Literature study is carried out through various references both binding legal materials such as laws and regulations, journals and books and other required data. The data were analyzed by using qualitative and quantitative methods

\section{RESULTS AND DISCUSSION}

\section{A. Damage Pattern Forests and Their Relation to Natural Disasters That Occur}

Efforts to protect ecosystems and forest function resilience in the City and District of Bima continue to be carried out in order to increase sustainable forestry development, but this hope is still far from hopeful, because every year forest damage continues to change, there are many factors that cause forest destruction and diversion. forest function in Bima. Consider the following Table I.

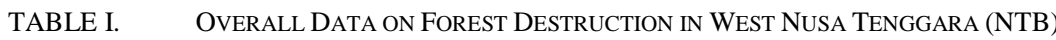

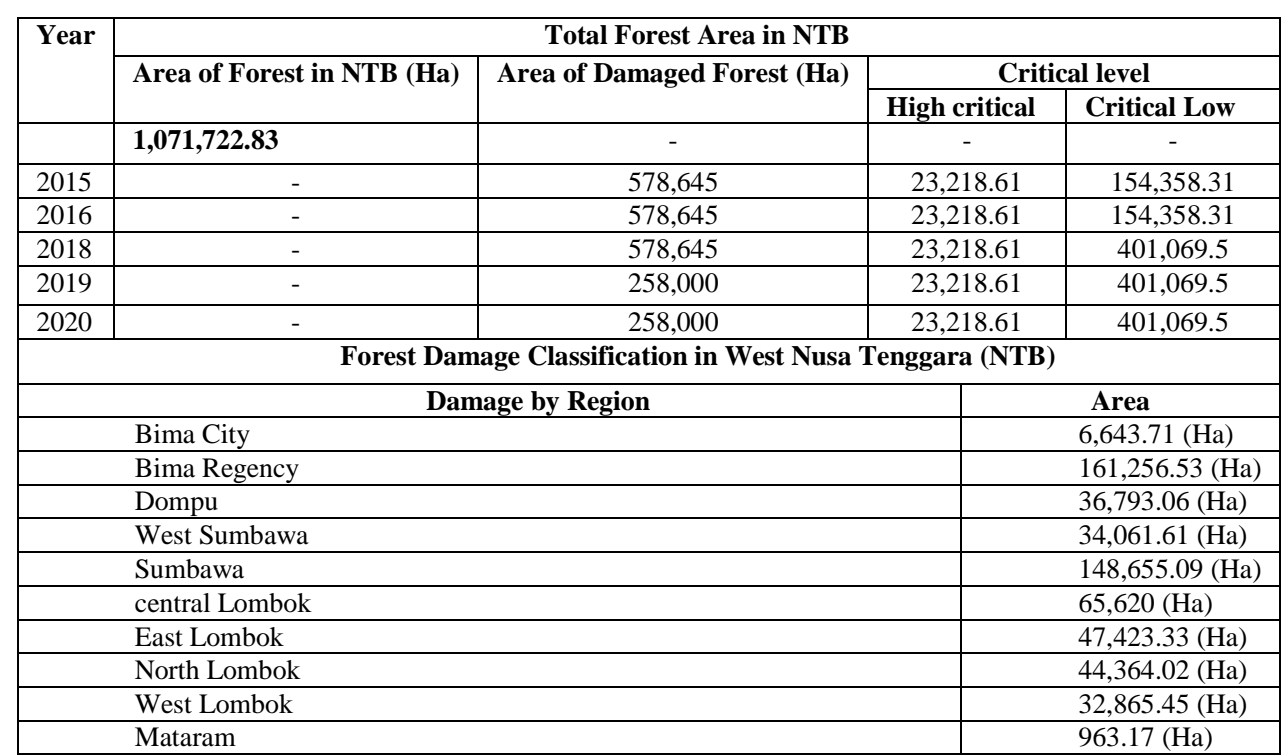

Environmental issues in the City and District of Bima are almost the same as environmental problems in other West Nusa Tenggara districts or cities. From the interview with Ms. Yuliati Basri, S.Hut., MM (the Head of Planning and Utilization Section, at the Maria Donggomasa Bima KPH Hall, Thursday 10 September 2020, at 10:43 pm), we found that the forest destruction in the City and District of Bima caused by various factors, including mining activities, illegal timber transportation, harvesting illegal logs (illegal logging). Furthermore, the law enforcement does not run effectively and the laws and regulations are less firm, so that the criminals were able to commit acts of destruction of the forest.
Deforestation occurs annually. It causes the change towards the area of protection debt in 2017 of the City of Bima starting from KH Maria RTK.25 forest which reaches 2,079.02 (Ha). KH Donggomasa RTK.67 reached 895.79 (Ha), and KH Nanganae RTK.68 reached 1,761.95 (Ha) and the total amount reached 4,736.76 (Ha), due to deforestation or deforestation in 2019 From the area of protected debt that reaches $4,736.76(\mathrm{Ha})$ to $225,744(\mathrm{Ha})$, it means that half of the protected debt is reduced and it can be ascertained that the reduced protected forest reaches 247,932 (Ha). Second, there is a change of land function, because there is a change in the function of land, the dry springs in the City of Bima continue to occur, another impact of land conversion, 
Furthermore, Immawan Muslimin, provided an overview of the connection with mining activities that carry out excavation in the City of Bima, there are several excavations that are indeed carried out by miners such as PT. TUKAD MAS in Rontu Urban Village, Bima City and C-Quarry Mining above the Rontu Mountain of Panggi Village. The existence of PT is indeed very threatening to the forest ecosystem and damaging the environment, thus creating pollution and dirty air around it, it's just that the existence of PT and Galian C is far from protected forest areas or land cover.

Based on data collected from the Environmental and Forestry Service of NTB Province-Balai KPH Maria Donggomasa Bima on Thursday, September 10 2020, some areas in the forest area in District of Bima are classified as high critical land, forests with a definitive area of 250.396 (hectares) or $50 \%$ of the total area of District of Bima are in urgent need of an intensive handling pattern, most of the forest area has exploited so that it has an impact on the loss of the function of forests and forest areas. Mining activities, land conversion and illegal logging continue to be carried out by a certain group of people, so that they have spread throughout the District of Bima, including Parado, Wawo, Lambitu, Langgudu, Wera, Ambalawi, Sape, Lambu, Belo, Palibelo, Sanggar, Tambora, Woha, Donggo, Monta, etc.

From the forest area based on its function, the protected forest area in District of Bima is around 82,866.11 (Ha), the Limited Production forest area is around 67,190.59 (Ha), while the Permanent Production forest area is 4474003 (Ha). From the area of the forest, especially the protected forest, there have been many changes seen from the number of activities in corn farming, illegal timber theft and mining, such as in each district. First, the conversion of forest functions from protected debt to plantation areas, reaching the highest percent of 18 Districts of Bima, the area of rice fields or plantations increased by $8.53 \mathrm{~km} 2$ when compared to 2008 which was $307.43 \mathrm{Km} 2$, an increase in area land area driven by the activities and activities of local communities, where these activities encroach on state-owned forests, from data on forest damage in the district with an area of damage reaching $161,256.53(\mathrm{Ha}), 50 \%$ is caused by illegal extraction of timber and encroachment of maize land, into state forest areas. Secondly, it is related to mining activities in Bima Regency such as coastal iron sand mining in Mawu Village, Ambalawi District which has been operating since 2014, the mining activity has resulted in damage to the plantation area owned by residents and the edge of the mountain, which is more severe related to mining activities and exploitation of gold without a permit in Pesa Village, Wawo District, Bima Regency, the mining is considered to be damaging to the environment and forest ecosystem (Results of Interview with Mr. Ahyar, S.HUT as Head of KPH Maria Donggomasa.

\section{B. Efforts to Prevent Forest Destruction}

According to Yuliati Basri, S.Hut., MM as the Head of Planning and Utilization Section, at the Maria Donggomasa Bima KPH Hall, there are several ways that the Maria Donggomasa KPH Unit Unit Team' takes as a step to prevent damage to special forests in the monitoring area of the Maria Donggomasa FMU. Among them is Making Gabion Wire Gabion wire is a tool in the form of iron that is made like a net and is long, the purpose of making this gabion wire is to slap as many rocks as possible, then install it on the edge of the forest or on the river bank. According to Ms. Yuliati, the installation of gabion wires is part of the government's efforts to prevent landslides in areas of deforested forest.

According to Jainudin ST as Head of Prevention and Preparedness at BPBD Bima City who was interviewed on 9 September 2020 at 11:12 AM, efforts to prevent forest damage, floods and landslides, the first is to do mitigation, especially in residential areas, the second is to do in the upstream area, for example rice fields and corn fields, so the stern action taken is to stop planting corn.

Whereas Mari Donggomassa's KPH Hall has a Joint Team which is part of the Task Force (SATGAS). According to Mrs. Upik as the Nature Protection and Empowerment Staff at the Maria Donggomasa KPH Hall who was Interviewed on 10 September 2020, 11.00 AM, this task force is to prevent and eradicate forest damage covering the City and District of Bima, SATGAS consists of Kodim 1608 Bima, the Attorney General's Office, Police, Forestry Police, District and City of Bima's PP Police Unit, Maria Donggomasa KPH Hall Team, also involving the Head of Sub-District. and the Village Head.

Furthermore, Mrs. Upik stated that the formation of the SATGAS since the issuance of the NTB Governor's Decree Number 522-205 of 2018 concerning the Task Force (SATGAS) to prevent and eradicate forest destruction, in taking action and preventing forest destruction, the Joint Team for the KPH Hall Mari Donggomas also refers to the Regulation Minister of Environment and Forestry No.P.62 Year 2014 regarding Timber Utilization Permit. In terms of prevention or prosecution, the Joint Team is more on a persuasive approach in resolving existing cases, because we feel sorry for the perpetrators, perhaps more in the educational process.

Meanwhile, according to Ridwan. S. Sos as the Head of Preparedness Section of the BPBD of Bima City in taking action against forest destruction refers to Perda No. 4 of 2014 concerning the Implementation of Communication and Informatics, in connection with the regulation from the governmental province, the City BPBD has formed the Disaster Risk Development Forum, while BPBD has formed Kelurahan Tangguh in partnership with BPBD in taking action against environmental damage.

\section{Analysis}

Forest is an area that is occupied by plants, trees and accommodates all the biodiversity of flora and fauna, so it is very important for humans to protect and maintain forest sustainability, safeguarding forest ecosystems and the universe as part of the manifestation of human love for the condition of the universe. Hence, the state must put into effect the laws and regulations in order to manage and utilize forests as well as possible, as explained in Article 33 paragraph (3) of the 1945 Constitution. That the Earth, Water and Natural Resources contained therein are controlled by the State for the greatest possible prosperity for the people.

Law No. 41/1999 [2] concerning Forestry emphasizes that in forestry implementation, it must be based on the principles of Beneficial, Sustainable, Community, Justice, Togetherness, Openness and Integrity. This means that the Government and all elements of society are obliged to maintain the integrity of 
the forest in order to increase national development and create the principles of good governance in protecting and securing forest functions.

Preservation of forest ecosystems and environmental management has probably been done a lot by the City and District governments of Bima, it's just that the implementation and stages are considered less massive and organized, because forest destruction and clearing of land cover in the Bima region continue to increase from year to year. Based on the classification of forest damage in the Bima Region, NTB, the highest rate of damage was in the Bima Regency area which reached 161,256.53 (Ha) while the City of Bima reached $6,643.71 \mathrm{Ha}$ ) seen from its hectare area, the greater the damage to the forest in the Regency area of Bima.

Departing from the data on forest destruction collected by the Environment and Forestry Service in the area of the Maria Donggomasa KPH Hall, we conclude that government policies in the forestry sector do not lead to sustainable forest development, because currently the government and law enforcers have never acted decisively. It is useless for a lot of regulations and laws if there are still reproaches for the perpetrators to commit crimes such as illegal logging, encroachment (illegal mining), and plantations in forest areas without permits.

According to Mrs. Upik as the Nature Protection and Empowerment Staff at the Maria Donggomasa KPH Hall who was Interviewed on 10 September 2020, 11.00 AM, in carrying out prevention and prosecution of perpetrators or communities who carried out forest encroachment (Ocuvasi) and expanded land on state-owned protection debt, the Joint Team of Balai KPH Maria Donggomasa, which is a member of SATGAS, focused more on a persuasive approach and an educational process to increase people's awareness of the importance of safeguarding forest functions and integrity. Therefore, the Joint Team rarely resolves cases including forest destruction or land encroachment to the court level.

The persuasive approach is an alternative in resolving forestry cases, according to researchers, the persuasive approach has the potential to be bad for the law enforcement system itself, because the persuasive approach or solving cases out of court (Non-Litigation) seems bad and there is no clear common ground because in part large involving politicians, investors (capitalists), companies (corporation), bureaucrats and law enforcers themselves [6].

In resolving cases or cases of criminal acts such as illegal logging, forest conversion and illegal logging, the settlement process is not just resolving out of court (non-litigation) but competing the process must be up to the court (litigation), while for mining or companies that conducting mining activities as a legal sanction must be given administrative sanctions or cessation of activities deemed to be damaging to the environment [7].

\section{CONCLUSION}

Forest destruction due to illegal logging and other function changes is a complex problem to solve and has long implications, not only for the current generation. However, also for future generations, this is a general picture of what happens in Indonesia, not least especially in the City and District of Bima, the rainy season arrives facing flash floods and fails, it is the dry season's turn to prepare for fires, droughts, shortages. clean water. These various natural disasters are always occurring and recurring every year and it getting worse. Of the 1 million hectares of forest areas owned by NTB, the critical forest area is around 896 thousand hectares or 75 percent. Of the total forest in Bima Regency, 250,396.42 Ha and 3,079.33 Ha, Bima City is mostly critical, due to the change of function. Meanwhile, on the other hand, there are no signs of stopping the rate of forest destruction and the implication of this, namely natural disasters. The results of the study found that the pattern of forest destruction in the City and District of Bima was caused by illegal logging, forest encroachment, and land conversion. The causes or mortality are factors of economic demands, low public awareness, and lack of socialization from the authorities. Efforts to prevent and take action against forest destruction are carried out in the form of conducting patrols, afforestation or reforestation, installing wire braces or gabions, taking action against forest damage. The causes or mortality are factors of economic demands, low public awareness, and lack of socialization from the authorities. Efforts to prevent and take action against forest destruction are carried out in the form of conducting patrols, afforestation or reforestation, installing wire supports or gabions, taking action against forest damage. The causes or mortality are factors of economic demands, low public awareness, and lack of socialization from the authorities. Efforts to prevent and take action against forest destruction are carried out in the form of conducting patrols, afforestation or reforestation, installing wire supports or gabions, taking action against forest damage.

\section{REFERENCES}

[1] S. Wirendro, S. G. Nanggara, F. A. Nainggolan and I. Apriani, Potret Keadaan Hutan Indonesia, Periode 2000-2009, Forest Wacth Indonesia (FWI). Edisi Pertama. Bogor, 2011.

[2] UU No. 41 tahun 1999 tentang Kehutanan.

[3] M. Hafil, Kerusakan Hutan Jadi Masalah Serius di NTB. https://www.republika.co.id/berita/nasional/daerah/18/11/12/pi2of743 0-kerusakan-hutanjadi-masalah-serius-ntb, November 2018.

[4] W. Wartiningsih, "Pidana Kehutanan (Keterlibatan dan Pertanggung Jawaban Penyelenggara Kebijakan Kehutanan)", Setara Press, Malang, 2014

[5] M. Fajar dan A. Yulianto, Dualisme penelitian hukum: normatif \& empiris, Pustaka Pelajar, Yogyakarta, 2010.

[6] R. Ridwan, A. Absori, K. Dimyati, "Makna Lingkungan Perspektif Etik Profetik", AtTahrir, vol. 17, no. 2, 2017

[7] A. Absori, Hukum Penyelesaian Sengketa Lingkungan, Model Penyelesaian Sengketa Lingkungan dengan Pendekatan Partisipasif’. Surakarta: Muhammadiyah University Press, 2014 